ISSN 0258-7122

Bangladesh J. Agril. Res. 34(3) : 385-394, September 2009

\title{
IN VITRO ORGANOGENESIS OF LATIRAJ
}

\author{
M. J. HOSSAIN
}

\begin{abstract}
In vitro organogenesis of a lowland species of Colocasia esculenta sp. esculenta L. cv. Latiraj was assessed in relation to explant types (meristem, parenchymatous tissues and storage tissues); three levels of each of NAA, BAP, Kn, and 2,4-D; four culture environments, such as $16 \mathrm{~h} 3000$ lux light intensity, $24 \pm 2^{\circ} \mathrm{C}$, $24 \mathrm{~h}$ dark $+24 \pm 2^{\circ} \mathrm{C}$, $24 \mathrm{~h}$ dark $+30 \pm 3^{\circ} \mathrm{C}$, and $12 \mathrm{~h}$ diffuse light $+30 \pm 3^{\circ} \mathrm{C}$.

Only isolated meristem and parenchymatous tissues regenerated plants with various degree of morphogenic intensity with different combinations of growth regulators. Meristem under both light and dark and at $24 \pm 2{ }^{\circ} \mathrm{C}$ with upto $\mathrm{Kn} 3.0$ + NAA 3.0 showed proliferation with poor rate of growth, while Kn 1.0+ NAA 3.0 had comparatively good response. The parenchymatous tissues with above environments responded very quickly with varying degree of growth intensity. $\mathrm{Kn}+2,4-\mathrm{D}$ was found least effective on regeneration from any explants. NAA and BAP had an effect on proliferation of shoot, root and other growth characters from both meristem and parenchymatous tissues under both light and dark conditions at $24 \pm 2^{\circ} \mathrm{C}$. This combination showed a very high degree of proliferation and caused callusing to some extent when cultured at dark which developed shoots and roots quickly after transferring to light. Except NAA+BAP, no other combination formed stolon. The white colour storage tissues after 30 days turned yellowish followed by greenish with shiny pimples after 50 days indicating that the cultures with protocorm may be developed. Almost all the cultures under high temperature environments $\left(30 \pm 3^{\circ} \mathrm{C}\right)$ neither survived nor proliferated. The meristems also died within 15-20 days, while others within $25-30$ days. Thus, a temperature range of $30 \pm 3^{\circ} \mathrm{C}$ was in no way suitable for in vitro culture of lowland species of Colocasia esculenta cv. Latiraj.
\end{abstract}

Key Words: Organogenesis, auxins, cytokinins, meristem, parenchymatous tissues, storage tissues, Colocasia esculenta L. cv. Latiraj.

\section{Introduction}

The lowland species of Colocasia esculenta ssp. esculenta L. is locally known as Panikachu (lowland taro) and the only recommended cultivar in Bangladesh is known as Latiraj. It is grown in marshy land or in high land with artificial irrigation in about 40,000 ha of land in Bangladesh (Rashid, 1991). Nutritionally, this crop is highly rich, particularly the stolon, leaf blade, and leaf stalk. $100 \mathrm{~g}$ leaf blade of Colocasia esculenta ssp. esculenta L. contains about $115 \mathrm{mg}$ vit.-C, which is equivalent to $300 \mathrm{ml}$ orange juice in term of vit. C (Rashid, 1991). The

Principal Scientific Officer, Tissue Culture Lab, Horticulture Research Centre, BARI, Joydebpur, Gazipur, Bangladesh. 
cv. Latiraj is particularly excellent for producing stolon which can be used to prepare delicious dishes. There are other species of Colocasia esculenta ssp. esculenta L. which are grown for producing quality rhizome. The stolon of Latiraj contains very low acridity and has a yield potential of 40-50 tons of stolon per hectare (Rashid, 1991).

The recommended cv. Latiraj produces suckers which are the propagating materials. A large number of germplasm of lowland species of colocasia is now in collection of the Tuber Crops Research Centre. They are being cultivated in the field by conventional propagation method which involves more labour, more space, time and expensive but unsafe from natural hazards. It is observed that the diseased suckers survived poorly after planting in the field, which resulted in poor performance in respect of plant growth and yield. Akhond et al. (1997) partially examined the in vitro development of Colocasia esculenta L in relation to conservation of plantlets with high level of sucrose, while Tariguchi and Tanaka (1988) reviewed the extent of use of tissue culture for Colocasia esculenta. According to them, most of the species of Colocasia esculenta contaminated with endogenous pathogens and thus it is difficult to obtain disease free planting materials, although disease free planting materials may be developed through repeated meristem culture (Hartman, 1974; Staritsky et. al., 1986). Westcott et al. (1977), Staritsky et al. (1986), Pathirana (1991) and Akhond et al. (1997) used different levels of sucrose in order to prolong the subculture interval.

Some researchers have tried to develop in vitro maintenance techniques of different species of taro (Staritsky et al., 1977; Bessembinder et al., 1993) and Yamamoto and Matsumoto (1992) studied the corm formation and growth habit of Colocasia escutenta. However, a suitable protocol for in vitro differentiation and propagation of Cotocasia esculenta are yet to be determined. Therefore, this experiment was designed to develop a suitable tissue culture protocol using different explants of lowland species of colocasia.

\section{Materials and Method}

About 15-20 cm tall suckers of the recommended cultivar Latiraj were used. Three different parts, such as meristem, parenchymatous tissues and storage tissues were used as explants. The size of excised meristem varied from 0.5 to $0.8 \mathrm{~mm}$ long, while parenchymatous tissues and storage tissues were cut into cubes, weighed to about $300-350 \mathrm{mg}$.

All the leaves of the suckers were cut off, leaving only 2-2.5 cm long suckers. The rhizome part was cleared by peeling off the outer layer with a knife carefully. The explants were sterilized by washing in running tap water followed by $70 \%$ ethanol for three times (10 minutes each time) and 10 minutes soaked in $1.5 \%$ chlorine water with few drops of Tween 20 . The explants were then washed 
with distilled and autociaved water for five times under laminar air flow cabinet (Hossain, 1988).

Organic salts of MS media were used. Four different plant growth regulators ( 2 from auxin group and 2 from cytokin group) each at three different levels \{auxins: a) NAA: $1.0,2.0$, and $3.0 \mathrm{mg} / \mathrm{l}$; b) 2,4-D: 3.0, 6.0, and $9.0 \mathrm{mg} / \mathrm{l}$ and cytokinin: c) Kn: 1.0, 3.0, and $5.0 \mathrm{mg} / \mathrm{l}$; d) BAP: 1.0, 5.0, and $10.0 \mathrm{mg} / \mathrm{l}\}$ were used. Three culture media were prepared combining $\mathrm{Kn}+\mathrm{NAA}, \mathrm{Kn}+2,4-\mathrm{D}$ and NAA+BAP in all possible combinations. There were 10 treatments in each group including the control (without growth regulators).

The cultures were incubated in four different environments \{a) $3.0 \mathrm{Kl}$ light intensity for $16 \mathrm{~h}$ and $24 \pm 2^{\circ} \mathrm{C}$; b) $24 \mathrm{~h}$ dark and $24 \pm 2^{\circ} \mathrm{C}$; c) $24 \mathrm{~h}$ dark and $30 \pm 3^{\circ} \mathrm{C}$; d) $12 \mathrm{~h}$ diffuse light and $30 \pm 3^{\circ} \mathrm{C}$. Five cultures were included in each replication. The data were analyzed using a CRD design and mean separation was done by LSD.

\section{Results and Discussion}

Isolated meristem cultured on MS media supplemented with $\mathrm{Kn}+\mathrm{NAA}$ and incubated in light or dark at $24 \pm 2^{\circ} \mathrm{C}$, showed poor response with low morphogenic intensity (Fig. la). The cultures responded upto Kn 3.0+ NAA 3.0 and no differentiation occurred when Kn increased upto 5.0. Here, NAA levels seemed to be ineffective because all levels of NAA with upto Kn 3.0 showed response, which is indicative that $\mathrm{Kn} 5.0$ negatively affected in vitro differentiation of Colocasia esculenta. Mix-Wagner (1993) obtained 70-80\% regeneration of Colocasia esculenta with the addition of $2.0 \mathrm{mg} / \mathrm{I}$ BAP and 2.0 $\mathrm{mg} / 1$ NAA which increased to $80-110 \%$ with lowering the level of NAA to 1.0 $\mathrm{mg} / 1$. While cultures of the control responded more quickly than some other treatments which received PGR. On the average, differentiation occurred within 18 to 22 days in the light and 20 days in the dark. The morphogenic intensity was slightly better in the light (av. 2.5) than that occurred in the dark (av. 1.5). The cultures in the dark became albunated which upon transfer to the light after 10 to 12 days found to be pigmented and normal growth (Fig. Ib). It was observed that root growth was earlier than first open leaf came up. Root growth intensity was also poor (av. 2.0 per microplant). Zhou et al. (1998) cultutred Colocasia esculenta with different stress of $\mathrm{NaCI}$ and observed that roots of Colocasia esculenta were very much sensitive to $\mathrm{NaC} 1$ even root growth was slow in the treatment with NaCI. Plant height and number of open leaves per plant were also lower in the light than that in the dark. It was influenced by darkness which was reported earlier (Staritsky et al., 1977; Dodds and Roberts, 1985). Dark condition makes the plant lanky and tall. No sucker was formed. Dark condition found to have a positive effect on number of roots (max. 7 in dark and 5.0 in the light), while growth of root was better in the light $(\mathrm{av} .>8 \mathrm{~cm}$ ) than in the dark (av. 3.5 
$\mathrm{cm})$. An early dark treatment for a period of at least 2 weeks was found to have a poor effect on overall in vitro development of Colocasia esculenta. But the growth intensity of plant under both light and dark conditions was not satisfactory. Moreover, new shooting and rooting delayed, probably $\mathrm{Kn}$ and NAA in combination with the stated levels was not effective for in vitro organogenesis of Colocasia esculenta.

Table 1. In vitro morphogenesis of Colocasia esculenta L. cv. Latiraj with meristem cultured on MS media with different combinations of $\mathrm{Kn}+\mathrm{NAA}$ at $16 \mathrm{~h} 3000$ lux light or dark and at $24 \pm 2^{\circ} \mathrm{C}$.

\begin{tabular}{|c|c|c|c|c|c|c|c|c|}
\hline \multirow[t]{2}{*}{ Treatments } & \multicolumn{3}{|c|}{ Days to } & \multicolumn{3}{|c|}{ Plant growth status } & \multicolumn{2}{|c|}{$\begin{array}{c}\text { Rooting } \\
\text { status }\end{array}$} \\
\hline & $\begin{array}{l}\text { differentia- } \\
\text { tion }\end{array}$ & shooting & rooting & $\begin{array}{l}\text { ht. } \\
\mathrm{cm}\end{array}$ & $\begin{array}{l}\text { leaf } \\
\text { no. }\end{array}$ & $\begin{array}{c}\text { sucker } \\
\text { no. }\end{array}$ & No. & $\begin{array}{l}\text { length } \\
(\mathrm{cm})\end{array}$ \\
\hline \multicolumn{9}{|l|}{ Light } \\
\hline Kn 1.0+NAA 1.0 & 18 & 226 & $182+$ & 1.5 & 2.0 & 0 & 5.0 & 5.0 \\
\hline Kn 1.0+NAA2.0 & 18 & 24 & $222+$ & 1.5 & 2.0 & 0 & 3.0 & 5.0 \\
\hline Kn 1.0+NAA3.0 & $202+$ & $246+$ & $172+$ & 1.0 & 2.0 & 0 & 3,0 & 2.0 \\
\hline Kn 3.0+NAA 1.0 & $202+$ & $246+$ & $242+$ & 1.5 & 2.0 & 0 & 3.0 & $>8.0$ \\
\hline Kn 3.0+NAA2.0 & $222+$ & 23 & $242+$ & 1.0 & 2.0 & 0 & 2.0 & 2.0 \\
\hline Kn 3.0+NAA3.0 & $222+$ & 24 & $242+$ & 1.5 & 2.0 & 0 & 2.0 & 5.0 \\
\hline Control & $182+$ & $282+$ & $182+$ & 1.5 & 2.0 & 0 & 3.0 & 2.0 \\
\hline Lsd 1\% & 2.23 & 2.56 & 1.69 & ns & ns & na & 1.35 & 2.45 \\
\hline \multicolumn{9}{|l|}{ Dark } \\
\hline Kn 1.0+NAA 1.0 & $22^{\prime}$ & 24 & $222+$ & 1.5 & 2.0 & 0 & 5.0 & 3.5 \\
\hline Kn 1.0+NAA 2.0 & $24{ }^{\prime}$ & $26^{\prime}$ & 22 & 1.75 & 2.0 & 0 & 2.0 & 2.5 \\
\hline Kn 1.0+NAA 3.0 & $206+$ & $256+$ & 222 & 2.5 & 3.0 & 0 & 7.0 & 2.5 \\
\hline Kn3.0+NAA 1.0 & 24 & 26 & 22 & 1.5 & 2.0 & 0 & 2.0 & 3.0 \\
\hline Kn 3.0 + NAA 2.0 & 22 & 25 & $222+$ & 2.0 & 4.0 & 0 & 4.0 & 2.0 \\
\hline Kn 3.0+NAA 3.0 & 221 & $25^{\prime}$ & $222+$ & 2.0 & 2.0 & 0 & 5.0 & 2.5 \\
\hline Control & 20 & $282+$ & $222+$ & 2.0 & 2.0 & 0 & 4.0 & 3.0 \\
\hline Lsd 1\% & 0.97 & 2.12 & ns & ns & 0.36 & na & 0.56 & 0.45 \\
\hline
\end{tabular}

Ns, Not significant; na, Not analysed

* =After transfering to light condition

$+=$ indicates infensity (used 1-6 seale, $1=$ very poor and $6=$ excellent) 
Table 2. In vitro morphogenesis of Colocasia esculenta L. cv. Latiraj with parenchymatous tissues cultured on MS media with different combinations of $\mathrm{Kn}+\mathrm{NAA}$ at $16 \mathrm{~h} 3000$ lux light or dark and at $24 \pm 2^{\circ} \mathrm{C}$.

\begin{tabular}{|c|c|c|c|c|c|c|c|c|}
\hline \multirow[t]{2}{*}{ Treatments } & \multicolumn{3}{|c|}{ Days to } & \multicolumn{3}{|c|}{ Plant growth status } & \multicolumn{2}{|c|}{$\begin{array}{c}\text { Rooting } \\
\text { status }\end{array}$} \\
\hline & $\begin{array}{l}\text { differentia- } \\
\text { tion }\end{array}$ & shooting & rooting & $\begin{array}{l}\text { ht. } \\
\mathrm{cm}\end{array}$ & $\begin{array}{l}\text { leaf } \\
\text { no. }\end{array}$ & $\begin{array}{c}\text { sucker } \\
\text { no. }\end{array}$ & No. & $\begin{array}{c}\text { length } \\
(\mathrm{cm})\end{array}$ \\
\hline \multicolumn{9}{|l|}{ Light } \\
\hline Kn 1.0+NAA 1.0 & $12^{5+}$ & $15^{5+}$ & $15^{5+}$ & 5.0 & 2.0 & 0 & 6 & 1.6 \\
\hline Kn 1.0+NAA 2.0 & $12^{5+}$ & $18^{5+}$ & $16^{5+}$ & 3.0 & 3.0 & 0 & 5 & 1.0 \\
\hline Kn 1.0+NAA 3.0 & $10^{6+}$ & $17^{6+}$ & $20^{6+}$ & 3.5 & 3.0 & 0 & 6 & 1.0 \\
\hline Kn 3.0+NAA 1.0 & $12^{5+}$ & $18^{5+}$ & $17^{5+}$ & 3.5 & 4.0 & 0 & 8 & 1.5 \\
\hline Kn 3.0+NAA 2.0 & $13^{5+}$ & $17^{5+}$ & $17^{5+}$ & 4.5 & 4.0 & 0 & 5 & 1.0 \\
\hline Kn 3.0+NAA 3.0 & $12^{5+}$ & $18^{5+}$ & $18^{5+}$ & 3.5 & 3.0 & 0 & 5 & 1.0 \\
\hline Kn 5.0+NAA 1.0 & $12^{5+}$ & $17^{5+}$ & $20^{5+}$ & 4.5 & 3.0 & 0 & 5 & 1.0 \\
\hline Kn 5.0+NAA 2.0 & $12^{5+}$ & $18^{5+}$ & $19^{5+}$ & 3.0 & 3.0 & 0 & 5 & 1.0 \\
\hline Kn 5.0+NAA 3.0 & $12^{5+}$ & $16^{5+}$ & $17^{5+}$ & 3.5 & 3.0 & 0 & 8 & 1.0 \\
\hline Control & $20^{1+}$ & $22^{5+}$ & $18^{5+}$ & 2.5 & 2.0 & 0 & 5 & 3.5 \\
\hline Lsd 1\% & 3.98 & ns & ns & ns & ns & ns & ns & ns \\
\hline \multicolumn{9}{|l|}{ Dark } \\
\hline Kn 1.0+NAA 1.0 & $10^{5+}$ & $12^{5^{+}}$ & $12^{4+}$ & 7.0 & 4 & 0 & 4 & 1.5 \\
\hline Kn 1.0+NAA 2.0 & $12^{5+}$ & $13^{5+}$ & $12^{6+}$ & 5.0 & 4 & 0 & 3 & 2.0 \\
\hline Kn 1.0+NAA 3.0 & $10^{6+}$ & $12^{6+}$ & $10^{6+}$ & 5.0 & 3 & 0 & 7 & 2.0 \\
\hline Kn 3.0+NAA 1.0 & $10^{5+}$ & $14^{5+}$ & $10^{6+}$ & 8.0 & 4 & 0 & 10 & 2.5 \\
\hline Kn 3.0+NAA 2.0 & $12^{5+}$ & $13^{5+}$ & $12^{++}$ & 5.0 & 4 & 0 & 6 & 1.5 \\
\hline Kn 3.0+NAA 3.0 & $8^{5+}$ & $12^{5+}$ & $10^{4+}$ & 6.5 & 3 & 0 & 3 & 2.5 \\
\hline Kn 5.0+NAA 1.0 & $8^{5+}$ & $13^{5+}$ & $10^{5+}$ & 6.0 & 3 & 0 & 8 & 1.5 \\
\hline Kn 5.0+NAA 2.0 & $10^{5+}$ & $11^{5+}$ & $12^{5+}$ & 6.5 & 3 & 0 & 10 & 2.5 \\
\hline Kn 5.0+NAA 3.0 & $10^{5+}$ & $12^{5+}$ & $10^{5+}$ & 6.8 & 3 & 0 & 4 & 3.0 \\
\hline Control & $20^{1+}$ & $20^{2+}$ & $26^{4+}$ & 2.5 & 3 & 0 & 4 & 2.5 \\
\hline Lsd 1\% & 3.39 & 2.11 & ns & 2.12 & ns & ns & 3.16 & ns \\
\hline
\end{tabular}

Ns, Not significant; na, Not analyzed

* =After transfering to light condition

$+=$ indicates infensity (used 1-6 seale, 1=very poor and 6= excellent)

Parenchymatous tissues was cultured on MS with the same combinations of $\mathrm{Kn}+\mathrm{NAA}$ as of meristem culture. Parenchymatous tissues cultured at both light 
and dark conditions showed very good response in respect to differentiation, new shooting, and rooting. The cultures of most of the treatments differentiated within 8-12 days when cultured in the dark, which after 2 weeks found to be albunated and transferred to the light condition. Otherwise, dark condition was better for most of the parameters than the light condition. Moreover, parenchymatous tissues showed excellent growth intensity (av. $>5$ in a 1-6 scale) for days to new shooting and rooting (Fig. 1c). The control treatment showed performance as previously in respect of growth and morphogenic intensity. The cultures which initially received a 2-week dark condition showed better shoot and root growth status than those in light from starting. In the light, plant attained maximum 5.0 $\mathrm{cm}$ height with 4 leaves compared to $8 \mathrm{~cm}$ height and 4 leaves in the dark. No stolon was formed. Number of roots per plant was higher in the dark condition (max. 10 roots and max. length $3.0 \mathrm{~cm}$ ) as compared to light condition (max. 8 roots and max. length $1.6 \mathrm{~cm}$ ). The cultures of the control treatment under both light and dark conditions formed 1-5 roots having 2.5 - $3.5 \mathrm{~cm}$ long (Table 2).Table 3 shows performance of excise meristems cultured on MS with NAA + BAP. Differentiation and rooting appeared almost at the same time ( about 15 days), while new shooting was earlier when the cultures received early dark treatment than these were at the light from starting, which agreed with the findings described earlier (Staritsky et al., 1977; Bessembinder et al., 1993). Plant growth status in terms of plant height, number of leaves and number of suckers was quite good in comparison to control. NAA + BAP has a very good effect on sucker development (Fig. 1d). No sucker was developed in some treatments at random (Table 3). The reason is obscure. While the cultures which were kept in the dark for 15 days initially developed stolons profusely, which is indicative that initial dark condition has a positive effect on stolon development. Under light condition, the maximum number of roots per plant was 6 with NAA 1.0 or 2.0 and BAP 10.0 or 1.0. These treatments also formed similar number of roots per plant under dark condition. The maximum length of root under both light and dark condition were 4.5 and $3.6 \mathrm{~cm}$, respectively, against 3.0 and 4.8 cm under the control treatment, respectively. Mix-Wagner (1993) used CCC, BAP, NAA and zeatin at different concentrations to maximize regeneration of plantlets from callus mass of Colocasia esculenta in order to obtain higher regeneration rate (85-102.5\%) with $2.0 \mathrm{mg} / \mathrm{l} \mathrm{BAP}+2.0 \mathrm{mg} / \mathrm{l} \mathrm{NAA}$, which was also increased by lowering the level of NAA $(0.1 \mathrm{mg} / \mathrm{l})$. Yam et al. (1991) tried to increase the rooting status of in vitro plantlerts of Colocasia esculenta with the addition of $100 \mathrm{ml}$ coconut water in $1 / 2$ strength MS.

Isolated parenchymatous storage with NAA + BAP cultured at $16 \mathrm{~h}$ light or dark and at $24^{\circ} \mathrm{C}$ showed excellent growth performance (Table 4). Differentiation occurred within 10-12 days against 20 days in the control. While new leaf and root growth noticed almost simultaneously after 13-16 days, which was 22 to 26 for the control. The cultures in the dark with the start of differentiation showed tendency 
of albunation and then transferred to light for better growth. In most of the treatments, plant growth and rooting status were quite good compared to the control (Fig. le). The parenchymatous storage tissues cultured on MS with NAA and BAP under light remained almost intact for the first 30 days and then turn to yellowish slowly which became greenish with shiny pimples after 50 days indicating that protocorm may be developed. The cultures in the dark neither proliferated nor survived though callus development occurred very slowly. Fig. 1.

Table 3. In vitro morphogenesis of Colocasia esculenta L. cv. Latiraj with meristem cultured on MS media with different combinations of NAA + BAP at 16h, 3000 lux light or dark and at $24 \pm 2^{\circ} \mathrm{C}$.

\begin{tabular}{|c|c|c|c|c|c|c|c|c|}
\hline \multirow[t]{2}{*}{ Treatments } & \multicolumn{3}{|c|}{ Days to } & \multicolumn{3}{|c|}{ Plant growth status } & \multicolumn{2}{|c|}{$\begin{array}{c}\text { Rooting } \\
\text { status }\end{array}$} \\
\hline & $\begin{array}{c}\text { differen- } \\
\text { tiation }\end{array}$ & shooting & rooting & $\begin{array}{l}\text { ht. } \\
\mathrm{cm}\end{array}$ & $\begin{array}{l}\text { leaf } \\
\text { no. }\end{array}$ & $\begin{array}{c}\text { sucker } \\
\text { no. }\end{array}$ & No. & $\begin{array}{c}\text { length } \\
(\mathrm{cm})\end{array}$ \\
\hline \multicolumn{9}{|l|}{ Light } \\
\hline NAA 1.0+BAP 1.0 & $12^{5+}$ & $15^{5+}$ & $15^{4+}$ & 3.6 & 3.0 & 0 & 4 & 4.5 \\
\hline NAAI.0+BAP5.0 & $10^{6+}$ & $16^{6+}$ & $17^{4+}$ & 3.5 & 2.0 & 2.0 & 5 & 3.0 \\
\hline NAA 1.0+BAP 10.0 & $14^{6+}$ & $15^{5+}$ & $17^{3+}$ & 4.8 & 3.0 & 2.0 & 4 & 35 \\
\hline NAA2.0+BAP 1.0 & $12^{5+}$ & $17^{6+}$ & $18^{6+}$ & 5.3 & 4.0 & 0 & 6 & 2.8 \\
\hline NAA2.0+BAP5.0 & $12^{5+}$ & $17^{6+}$ & $17^{5+}$ & 4.2 & 4.0 & 0 & 6 & 2.7 \\
\hline NAA2.0+BAP 10.0 & $14^{6+}$ & $15^{5+}$ & $16^{4+}$ & 3.6 & 4.0 & 3.0 & 5 & 3.5 \\
\hline NAA3.0+BAP 1.0 & $13^{5+}$ & $18^{5+}$ & $18^{4+}$ & 5.0 & 4.0 & 3.0 & 3 & 3.8 \\
\hline NAA3.0+BAP5.0 & $14^{5+}$ & $17^{5+}$ & $19^{6+}$ & 5.2 & 3.0 & 2.0 & 2 & 2.5 \\
\hline NAA3.O+BAP 10.0 & $12^{5^{+}}$ & $16^{5+}$ & $18^{3+}$ & 4.8 & 4.0 & 3.0 & 5 & 3.0 \\
\hline Control & $18^{1+}$ & $24^{2+}$ & $22^{4+}$ & 2.5 & 2.0 & 0 & 4 & 3.0 \\
\hline LSD 1\% & 2.31 & 1.89 & 1.01 & 0.56 & 0.35 & 0.11 & 0.32 & 0.21 \\
\hline \multicolumn{9}{|l|}{ Dark } \\
\hline NAA $1.0+B A P 1.0$ & $10^{3+}$ & $15^{4+}$ & $16^{4+}$ & 5.0 & 3.0 & 1.0 & 3 & 2.6 \\
\hline NAA 1.0+BAP5.0 & $12^{4+}$ & $16^{6+}$ & $17^{6+}$ & 5.6 & 3,0 & 2.0 & 2 & 1.5 \\
\hline NAA 1.0+BAP 10.0 & $14^{4+}$ & $16^{4+}$ & $16^{4+}$ & 5.4 & 4.0 & 2.0 & 6 & 2.8 \\
\hline NAA2.O+BAP 1.0 & $13^{5+}$ & $14^{6+}$ & $15^{3+}$ & 4.8 & 3.0 & 3.0 & 6 & 3.0 \\
\hline NAA2.0+BAP5.0 & $10^{5+}$ & $14^{6+}$ & $17^{5+}$ & 5.5 & 4,0 & 3.0 & 5 & 3.0 \\
\hline NAA2.0+BAP 10.0 & $12^{6+}$ & $15^{4+}$ & $17^{5+}$ & 3.8 & 2.0 & 4.0 & 3 & 2.8 \\
\hline NAA3.0+BAP 1.0 & $12^{4+}$ & $15^{5+}$ & $18^{6+}$ & 5.0 & 3.0 & 3.0 & 2 & 3.2 \\
\hline NAA3.0+BAP5.0 & $10^{3+}$ & $16^{3+}$ & $17^{3+}$ & 4.3 & 2.0 & 3.0 & 2 & 3.6 \\
\hline NAA3.0+BAP 10.0 & $13^{2+}$ & $17^{5+}$ & $18^{5+}$ & 4.8 & 2.0 & 3.0 & 2 & 3.3 \\
\hline Control & $20^{2+}$ & $24^{1+}$ & $25^{4+}$ & 2.3 & 2.0 & 0 & 5 & 4.8 \\
\hline LSD 1\% & 1.69 & 2.01 & 1.70 & 0.36 & 0.23 & 0.45 & 0.12 & 0.46 \\
\hline
\end{tabular}

* After transferring to light condition

+Indicates intensity (using 1-6 arbitrary scale, 1 = very poor and 6 =excellent)

Different stages of in vitro growth and development of Colocasia esculenta sp. esculenta L., a) Isolated meristem cultured on MS media supplemented with $\mathrm{Kn}+\mathrm{NAA}$ and incubated in light or dark at $24 \pm 2^{\circ} \mathrm{C}$ showed poor response with 
low morphogenic intensity, b) The microplants became pigmented and showed normal growth upon transfer to light condition from dark after 10- 12 days, c) Microplants derived from parenchymatous tissues showed excellent growth intensity, d) The culture in combination of NAA and BAP gave excellent growth performance with sucker development, and e) The growth of microplants was better in most of the treatments compared to the control (microplant on the right received PGR and on the left did not).

Table 4. In vitro morphogenesis of Colocasia esculenta L. cv. Latiraj with parenchymatous storage cultured on MS media with different combinations of NAA+BAP at $16 \mathrm{~h} 3000$ lux light and dark and at $24 \pm 2^{\circ} \mathrm{C}$.

\begin{tabular}{|c|c|c|c|c|c|c|c|c|}
\hline \multirow[t]{2}{*}{ Treatments } & \multicolumn{3}{|c|}{ Days to } & \multicolumn{3}{|c|}{ Plant growth status } & \multicolumn{2}{|c|}{$\begin{array}{c}\text { Rooting } \\
\text { status }\end{array}$} \\
\hline & $\begin{array}{c}\text { differenti } \\
\text { a-tion }\end{array}$ & shooting & rooting & $\begin{array}{l}\text { ht. } \\
\text { cm }\end{array}$ & $\begin{array}{l}\text { leaf } \\
\text { no. }\end{array}$ & $\begin{array}{c}\text { sucker } \\
\text { no. }\end{array}$ & No. & $\begin{array}{c}\text { length } \\
\text { (cm) }\end{array}$ \\
\hline \multicolumn{9}{|l|}{ Light } \\
\hline NAA $1.0+B A P 1.0$ & $12^{5+}$ & $16^{5+}$ & $14^{3+}$ & 4.5 & 3.0 & 2 & 3 & 4.5 \\
\hline NAAI.0+BAP5.0 & $10^{5+}$ & $12^{5+}$ & $14^{3+}$ & 3.5 & 2.0 & 0 & 5 & 2.0 \\
\hline NAA $1.0+B A P 10.0$ & $\mathrm{i}^{5+}$ & $12^{5+}$ & $13^{2+}$ & 3.0 & 3.0 & 0 & 4 & 2.0 \\
\hline NAA2.0+BAP 1.0 & $12^{5+}$ & $13^{5+}$ & $16^{2+}$ & 4.0 & 3.0 & 3 & 3 & 2.5 \\
\hline NAA2.0+BAP5.0 & $12^{5+}$ & $17^{5+}$ & $14^{3+}$ & 2.5 & 2.0 & 0 & 3 & 2.5 \\
\hline NAA2.0+BAP 10.0 & $12^{5+}$ & $15^{5+}$ & 0 & 3.5 & 2.0 & 0 & 0 & 0 \\
\hline NAA3.0+BAP 1.0 & $10^{5+}$ & $13^{5+}$ & 0 & 3.5 & 2.0 & 2 & 0 & 0 \\
\hline NAA3.0+BAP5.0 & $10^{5+}$ & $13^{5+}$ & $13^{2+}$ & 2.0 & 4.0 & 2 & 4 & 2.5 \\
\hline NAA3.0+BAP 10.0 & $12^{5+}$ & $16^{5+}$ & $13^{2+}$ & 2.5 & 2.0 & 2 & 4 & 3.0 \\
\hline Control & $20^{2+}$ & $22^{2+}$ & $26^{2+}$ & 2.0 & 2.0 & 0 & 3 & 3.0 \\
\hline LSD 1\% & ns & 3.45 & na & ns & ns & na & na & na \\
\hline \multicolumn{9}{|l|}{ Dark } \\
\hline NAA $1.0+B A P 1.0$ & $12^{5+}$ & $15^{5+}$ & $22^{5+}$ & 3.5 & 2.0 & 2.0 & 5.0 & 4.5 \\
\hline NAA $1.0+B A P 5.0$ & $12^{5+}$ & $13^{5+}$ & $23^{5+}$ & 2.8 & 3.0 & 1.0 & 4.0 & 3.5 \\
\hline NAA $1.0+B A P 10.0$ & $10^{5+}$ & $12^{5+}$ & $20^{5+}$ & 5.0 & 2.0 & 1.0 & 6.0 & 4.0 \\
\hline NAA2.O+BAP 1.0 & $10^{5+}$ & $15^{5+}$ & $24^{5+}$ & 3.0 & 3.0 & 2.0 & 3.0 & 2.5 \\
\hline NAA2.0+BAP5.0 & $12^{5+}$ & $14^{5+}$ & $24^{5+}$ & 5.0 & 3.0 & 3.0 & 4.0 & 3.0 \\
\hline NAA2.0+BAP 10.0 & $12^{5+}$ & $14^{5+}$ & $22^{5+}$ & 3.0 & 2.5 & 3.0 & 8.0 & 4.0 \\
\hline NAA3.0+BAP 1.0 & $11^{5+}$ & $15^{5+}$ & $22^{5^{+}}$ & 3.5 & 2.5 & 4.0 & 10.0 & 4.5 \\
\hline NAA3.0+BAP5.0 & $11^{5+}$ & $13^{4+}$ & $24^{5+}$ & 3.5 & 3.0 & 3.0 & 8.0 & 4.5 \\
\hline NAA3.0+BAP 10.0 & $12^{5+}$ & $14^{4+}$ & $23^{5+}$ & 4.5 & 4.0 & 2.0 & 8.0 & 3.5 \\
\hline Control & $20^{2+}$ & $21^{2+}$ & $14^{5+}$ & 2.0 & 2.0 & 0 & 6.0 & 2.5 \\
\hline LSD 1\% & 3.16 & 2.22 & ns & 1.34 & ns & na & 2.22 & 1.89 \\
\hline
\end{tabular}

Ns, Not significant; na, Not analyzed

* After transfering to light condition,

+ Indicates intensity (used 1-6 arbitrary scale, 1 = very poor and 6 =excellent) 


\section{Conclusion}

From the above discussion, it may be concluded that meristem or parenchymatous tissues were equally good for plant regeneration of Colocasia esculenta. Though $\mathrm{Kn}$ and NAA in combination found active for plant regeneration. $\mathrm{Kn}$ and 2,4-D were ineffective for either callusing or regeneration. All levels of BAP (1.0, 5.0, and $10.0 \mathrm{mg} / \mathrm{l})$ and NAA (1.0, 2.0, and $3.0 \mathrm{mg} / \mathrm{l})$ in combination were found very good for plantlet regeneration from both meristem and parenchymatous tissues under both light and dark conditions. The developed plantlets under the dark became lanky and light greenish compared to that of light (luxuriant growth and deep green foliage). No culture at $30 \pm 3^{\circ} \mathrm{C}$ either survived or proliferated.

\section{References}

Acedo, V.Z., A.Q. Villordon and E.S. Quevedo. 1994. Callus induction in yam (Dioscorea alata L.). J. Root Crops. 20: 64-67.

Hartman, R.D. 1974. Dasheen mosiac virus and other phytopathogens eliminated from caladium, taro and cocoyam by cultures of shoot tips. Phytopath. 64: 237-240.

Hossain, M.J. 1988. In vitro node culture of potato (Solanum tuberosum L.). Bangladesh Hort. 16: 1-7.

Mix-Wagner, G. 1993. In vitro multiplication of white yam (Dioscorea esculenta Poir) and taro (Colocasia esculenta L.) for planting materials production. Landbauforschung-Volkenrode 43: 93-100.

Nair, N.G. and S. Chandrababu. 1994. A slow growth medium for in vitro conversation of edible yams. J. Root Crops. 20: 68-69.

Pathirana, R. 1991. Conservation of plant genetic resources through in vitro methods. In: Zakri, A.H., M.N. Normah, A.G.A.Karim, M.T.Senawi (eds.) proc. of the MNCPGR/CSC Int'l Workshop on tissue culture for the conservation of biodersity and plant genetic resources. FRIM/MNCPGR, Kuala Lumpur, Malaysia, pp. 2 13-230.

Rashid, M.M. 1991. Transferable technologies in tuber crops. Tuber Crops Res. Centre, Bangladesh Agril. Res. Inst., Joydebpur, Gazipur-1701, pp.1-14.

Staritsky, G., A.J. Dekkers, N.P. Louwaars and E.A. Zandvoort. 1986. In vitro conservation of aroid germplasm at reduced temperatures and under osmotic stress. In: Withers, L.A., P.G.Alderson (eds.) Plant Tissue Culture and its Agricultural Applications. Butterworths, London, pp. 277-283.

Taniguchi, K. and R. Tanaka. 1988. The use of tissue culture for the production of a large number of plants. Agric. \& Hort. 63: 1279-1283.

Westcott, R.J., G.G. Henshaw and W.M. Roca.1977. Tissue culture of potato germplasm: culture iniatiation and plant regenaration. Plant Sci. Lett. 9: 309-3 15. Cited in: Bhojwani, S.S. and M.K. Razdan (1983) Plant Tissue Culture:Theory and Practices, Elsivier, The Netherlands p. 383. 
Yam, T.W., S. Ichihashi and J. Arditti. 1991 Callus growth and plantlet regeneration in taro (Colocasia esculenta var esculenta (L) Schott.

Yamamoto, Y. and 0. Matsumoto. 1992 In vitro corm formation and growth habit of propagated seed corm in taro (Colocasia esculenta Schott). Japanese Soc. Hort. Sci. 61: 55-61.

Akhond, M.A.Y, M.0. Islam and M. Ali. 1997. In vitro conservation of taro (Colocasia escuenta var. antiquorum) under different sucrose levels. Plant Tissue Culture 7(2): 81-88.

Zhou, S.P., S.J. Li and Y.K. He. 1998. Effects of Nacl on: I. Plantlet and in vitro corm development. II. Callus growth in taro. Advances in Horticulture 2: 650-653. 